\title{
Urgences
}

\section{Comme au théâtre...}

\section{Marie-Rose Comeau}

Numéro 13, mars 1986

Éclats d'atelier

URI : https://id.erudit.org/iderudit/025203ar

DOI : https://doi.org/10.7202/025203ar

Aller au sommaire du numéro

Éditeur(s)

Urgences

ISSN

0226-9554 (imprimé)

1927-3924 (numérique)

Découvrir la revue

Citer ce document

Comeau, M.-R. (1986). Comme au théâtre... Urgences, (13), 22-22.

https://doi.org/10.7202/025203ar

Ce document est protégé par la loi sur le droit d'auteur. L'utilisation des services d'Érudit (y compris la reproduction) est assujettie à sa politique d'utilisation que vous pouvez consulter en ligne.

https://apropos.erudit.org/fr/usagers/politique-dutilisation/
Cet article est diffusé et préservé par Érudit.

Érudit est un consortium interuniversitaire sans but lucratif composé de l’Université de Montréal, l'Université Laval et l'Université du Québec à Montréal. Il a pour mission la promotion et la valorisation de la recherche. https://www.erudit.org/fr/ 


\section{Marie-Rose Comeau}

Comme au théâtre des marionnettes, "et rose elle a vécu ce que vivent les roses, l'espace d'un matin." Mauvaise herbe le disait, lui, qui n'était pas de la marijuana et qui, comme tout bon romanichel, aux temps révolus, voulait oser compenser l'eau par du romarin.

Néanmoins, le mari de la reine Cléopâtre, loin de Rome, du Rhône, de la Saône et du Rubicon, se marrait en regardant un auguste se faire rosser par un comédien comique, lequel, tout marri par cette ruse, était un accompagnateur mélancolique provenant de la rousse, une coquille mi-pleine d'eau.

Au royaume des idées délirantes, j'ai vu, écrasées sur les murs, des marines brossées d'un gris commun sale qui me faisait penser à des eaux-fortes aux teintes toutes trop prononcées. Les concombres marinés au bain-marie et arrosés de vin rosé m'étaient offerts par des marins au teint couperosé comme des confitures aux framboises rubicondes.

Malgré tout, trois à quatre lignes m'ont moins affolée qu'une de trop, donc je prends mon essor unique avec modération, certaine de la quantité demandée par l'autorité. 